УДК 379.851

\title{
РАЗРАБОТКА ТУРМАРШРУТА ПО УСТЬ-АЛДАНСКОМУ УЛУСУ
}

\author{
Афанасьева Диана Афанасьевна \\ студент \\ Научный руководитель: Федорова Сардана Николаевна, \\ к.культурологии, доцент \\ ФГАОУ ВО “Северо-Восточный Федерельный \\ университет им. М.К. Аммосова”
}

Аннотация: В современном мире происходит развитие во многих отраслях и большое внимание уделяется европатизации (американизации) и в итоге может исчезнуть, позабыться культура многих народов. В следствии этого, разработка турмаршрута по музеям территории Усть-Алданского района (улуса) поможет узнать историю, обычаи и традиции народа саха

Ключевы слова: турмаршрут, традиции, музей-заповедник, народ саха, история.

\section{DECELOPMENT OF A TOUR ALONG THE UST-ALDAN ULUS}

\section{Afanasieva Diana Afanasievna Scientific adviser: Fedorova Sardana Nikolaevna}

\begin{abstract}
In the modern world, there is development in many industries and much attention is paid to Europeanization (Americanization), and as a result, the culture of many peoples may disappear and be forgotten. As a result, I developed a tour route through the museums of the territory of the Ust-Aldan district (ulus) in order to learn the history, customs and traditions
\end{abstract}

Key words: tour route, traditions, museum-reserve, Sakha people, history.

Индустрия туризма в Республике Саха (Якутия) представляет собой одну из наиболее динамично развивающихся отраслей экономики. Именно туризм дает возможность познакомиться с историей, культурой, обычаями, духовными ценностями народов северного края и уникальной природой Якутии.

В последнее время в связи с пандемией коронавируса COVID-19 структура туристских направлений поменялся. Переориентация туристов на 
внутренний туризм дает возможность исследования туристских продуктов в улусах республики. В связи с этим, чтобы занимать лидирующее положение нужно разобрать свой туристский продукт, который пользовался бы спросом у туристов.

В своем учебном пособии Большунова Т.В. пишет что результатом деятельности в туризме является туристский продукт, который имеет следующие особенности:

- спрос на туристские услуги, которые отвечают доходу потребителя;

- зависимость турпродуктов от таких переменных, как пространство и время;

- предлагаемые туруслуги и турпродукт отличаются негибким производством. Гостиницы, аэропорты, ммузеи, тематические парки не могут быть перенесены в конце туристского сезона в другой регион, чтобы приспособиться к изменению спроса и сезонности;

- на оценку качеств турпродукта влияет природные условия, политические события [1, с.20].

Отсюда следует вывод, что немаловажным фактором является грамотное и эффективное продвижение турпродукта на рынок. В данном случае турмаршрут в Усть-Алданском улусе должен иметь свою привлекательность, нуждается в разработке и продвижении.

Перед чем разобрать турмаршрут нужно посмотреть дефиницию «турмаршрут».

В википедии туристский маршрут - путь перемещения туристов, определяющий последовательное посещение исторических и природных памятников, а также других мест, например, мест остановок на привал [2].

По мнению М.Б. Биржакова, «туристский маршрут есть географически определенная, привязанная к данной местности и особенным объектам и описанная с различной степенью детальности трасса похода, путешествия». [1, c. 120]

Часто туристский маршрут в научных литературах определяют, как заранее спланированную трассу передвижения туристов в течение определенного периода времени с предусмотренной программой по культурным и природным достопримечательностям, с экскурсионной программой [3, с.22]. Туристские маршруты - один из основных видов обслуживания, предоставляемых туристам. Туристско-экскурсионные организации заранее разрабатывают маршруты с комплексом услуг по 
питанию, проживанию, экскурсий, различных анимационных мероприятий, дополнительных услуг.

В любом туристском маршруте определяется дорожная карта путешественника, где обозначается перечень всех географических пунктов и мест, последовательно посещаемых им во время путешествия. Обязательно в туристском маршруте указывается вид транспорта, используемый туристом для передвижения, время, видовые точки.

В республике имеются очень много турмаршрутов, которые востребованы туристами.

Некоторые улусы республики имеют свой туристический бренд, которым привлекают туристов. Например, в Хангаласском улусе - Ленские столбы, В Верхоянском - горы Кисилях, Намский улус - музей М.К. Аммосову, Таттинский улус - Черкехский музей под открытым небом и.т.д.

Усть-Алданский улус является одним из центральных районов Республики Саха (Якутия). В данном районе всего 21 наслегов.

Административный центр улуса - село Борогонцы.

Площадь района - 18,3 тыс. км². Граничит на востоке с Таттинским улусом, на юго-востоке - с Чурапчинским, на юге - с Мегино-Кангаласским, на западе - с Намским, на севере - с Кобяйским, на северо-востоке - с Томпонским районом [9].

В данном улусе население в основном занимается сельским хозяйством, в основном разведением животноводства и овощеводством: выращивают картофель, овощи и зерновые.

От столицы Республики Саха (Якутия) г. Якутска улус находится невдалеке и в 2022 году здесь будут проводится VIII спортивные игры народов Якутии. В связи с этим приедут со всех районов, улусов очень много спортсменов, болельщиков и предстоит большая работа по организацию питания и размещению гостей, но и предлагать развлекательные программы, в том числе туристские услуги. На данном этапе нет специальных турмаршрутов, поэтому данная тема очень актуальна.

На территории улуса находятся Ленский историко-архитектурный музейзаповедник «Дружба» (Соттинцы), Тандинский историко-революционный музей, Борогонский краеведческий музей.

Самый известный и посещаемый объект - это «Борогонский краеведческий музей». Это небольшой музей, который рассказывает и показывает об истории улуса, о его известных людях. В фондах музея: якутские чороны для кумысопития, берестяная посуда якутов-саха различного 
скотоводческого и коневодческого направлений, железные изделия кузнецов саха, якутские деревянные чаши-посуды и т.д. Музей расположен в центре Усть-Алданского района в селе Борогонцы [4].

Одним из культурных наследий Усть Алданского улуса является открытый музей под небом Ленский Историко-Архитектурный МузейЗаповедник «Дружба». Музей расположен на правом берегу реки Лены в 70 км от Якутска вниз по течению. Построен заповедник силами общественности на благотворительных началах на исторической точке первоначального основания г. Якутска («Ленский острог») в 1632 году русскими землепроходцами во главе «градоначатцем Петром Бекетовым с 30-ю сотоварищами». В центре музея под открытым небом находится копия Спасской церкви Зашиверского острога. Вокруг церкви расположены образцы деревянного зодчества народов, населяющих Якутию. В музее хранятся многочисленные экспонаты, рассказывающие о культуре коренных народов Севера Якутии. Впечатляет коллекция деревянных сосудов для кумыса (чоронов), выставка национальной одежды якутов 19-20-х веков, а также старинные украшения, якутские седла и захоронения, перенесенные из разных мест на территорию музея. Кроме того, в собрании музея много картин [5].

А также можно посетить «Тандинский историко-краеведческий музей им. И.П. Готовцева» 1947 г. в с. Танда Усть-Алданского улуса [6]. Этот музей организовал учитель И.П. Готовцев по собственному желанию. Первоначально музей мыслился им как краеведческий, отражающий историю улуса и наслега, но после главное внимание стало уделяться революционной тематике. Здесь можно услышать рассказ о политических ссыльных, увидеть их личные вещи. Кроме этого здесь хранятся предметы быта местного населения.

Еще один из культурных объектов является «Музей космонавтики и авиации им. Ю.А. Гагарина» экспозиции Музея Центра подготовки космонавтов им. Ю.А. Гагарина размещены в четырех залах. Каждый из залов рассказывает об истории зарождения, становления и совершенствования пилотируемых космических полетов, успехах и трагических событиях в деле освоения космоса, первом человеке планеты, преодолевшем силу земного притяжения [7].

Алас Мюрю - красивейший и самый большой алас в Якутии. Периметр аласа - 21,6 км, наибольшая длина (с востока на запад) - 13,2 км, ширина 6,75. На северной горке аласа Мюрю расположена местность под названием Томтор - центр Борогонского улуса (1805 по 1936 гг.). Сейчас данная местность практически заброшена. Благодаря старожилам, членам объединения 
«Томтор», краеведам местность включили в перечень объектов культурного наследия.

Усть-Алданский улус славится именами героев войны и труда, внесшими вклад в развитие родной республики. В 2005 году в с. Борогонцы была открыта Аллея Героев, в которой увековечены имена восьми из них [8].

Природное наследие Усть -Алданского улуса тоже привлекает туристов. Например, есть много озер, но самое большое это озеро Мюрю, Алыьардаахчистейшее место с песчаным дном, для того чтобы искупаться, таких мест не так мало. Любители активных отдыхов могут устроить пеший трип по аласам, но только в тёплые времена года.

В заключении можно сделать вывод, что во время исследования был изучен материал, характеризующий туристические маршруты и создана карта туристического маршрута «Усть-Алданский улус», дано описание маршрута и краткая характеристика достопримечательностей улуса и разработана развлекательная программа для туристов.

Узнавать что-то новое полезно и позволяет расширять кругозор. В УстьАлданском улусе много красивых мест, после посещения их туристы расширят свои познания или получат новые знания, связанные с народом саха. Вместе с тем не помешает активный отдых летом по аласам выражающееся в желании человека отдыхать в среде абсолютно безопасной для его здоровья (укрепляя, закаляя свое здоровье). Для более подробного ознакомления предлагаем ознакомиться с технологической картой турмаршрута (Приложение 1).

\section{Список литературы}

1. Большунова, Т. В. Управление маркетингом в туристской индустрии : учебное пособие / Т. В. Большунова. - Липецк : Липецкий государственный технический университет, ЭБС АСВ, 2018. - 165 с.

2. Туристский маршрут. [Электронный ресурс] - Режим доступа: https://ru.wikipedia.org/wiki

3. Биржаков М.Б. Введение в туризм. - СПб Издательский дом «Герда», 2000. C. 192

4. Усть-Алданский улус : история, культура, фольклор : в 3 книгах / Администрация муниципального района "Усть-Алданский улус (район)", Институт гуманитарных исследований и проблем малочисленных народов Севера СО РАН, МУ "Усть-Алданская межпоселенческая централизованная библиотечная система" ; [составители: А.Н. Жирков и др. ; редколлегия: 
А. Н. Жирков и др.]. - Якутск : Бичик, 2010- . - 29 см. - (Улусы Республики Саха (Якутия) / [гл. редкол. серии: А. С. Николаев (рук.) и др.]). Кн. 2: История УстьАлданского улуса в лицах : биобиблиографический справочник. - 2010. - 869 с.

5. Борогонский краеведческий музей [Электронный ресурс] - Режим доступа: https://www.culture.ru/institutes/3581/borogonskii-kraevedcheskii-muzei

6. Тандинский историко-краеведческий музей им. И.П. [Электронный pecypc] - Режим доступа: https://www.culture.ru/institutes/108/tandinskii-istorikokraevedcheskii-muzei-im-i-p-gotovcevaЛенский историко-архитектурный музейзаповедник «Дружба» [Электронный ресурс] - Режим доступа: https://www.culture.ru/institutes/12149/lenskii-istoriko-arkhitekturnyi-muzeizapovednik-druzhba

7. Музей космонавтики и авиации им. Ю.А. Гагарина [Электронный pecypc] - Режим доступа: https://www.culture.ru/institutes/9759/muzei-niicpodgotovki-kosmonavtov-im-yu-a-gagarina

8. Усть-Алданский улус [Электронный ресурс] - Режим доступа: https://ru.wikipedia.org/wiki/Усть-Алданский_улус

Приложение 1

\section{ТЕХНОЛОГИЧЕСКАЯ КАРТА ТУРИСТСКОГО МАРШРУТА}

1.Основные показатели маршрута.

Вид маршрута: автомобильный.

Протяженность маршрута (км): 338км. с г. Якутска

Продолжительность путешествия (суток): 4 дня/3ночи.

Число туристов в группе: 10-15 туристов.

Стоимость путевки (руб): 10000 руб. с чел.

2. Программа путешествия по маршруту.

Населенные пункты и расстояние между ними:

Якутск - Соттинцы - Борогонцы (127 км) - 4-5 часа езды

Борогонцы - Танда (42 км) - 1-1,5 часа езды

Танда - Борогонцы (42 км) - 1-1,5 часа езды

Борогонцы - Дюпсэ (46,3 км) - 2,5-3 часа езды

Дюпсэ - Борогонцы (46,3 км) - 2,5-3 часа езды

Борогонцы - Якутск (127км) - 4-5 часа езды 
Наименование туристских предприятий и условия размещения: гостиница «Мюрю» в селе Борогонцы.

Объекты посещения:

Ленский историко-архитектурный музей-заповедник «Дружба» (Соттинцы), Тандинский историко-революционный музей, Борогонский краеведческий музей.

1 день. Якутск-Соттинцы-Борогонцы

Выезд с Якутска в 8:00ч

Прибытие в Соттинцы 11:00ч

-экскурсия по музею-заповеднику «Дружба»

-обед (не включен)

Выезд в 14:00ч

Прибытие в Борогонцы 16:00ч

-посещение Борогонского-краеведческого музея

-ужин (не включен)

-гостиница «Муру» в Борогонце.

2 день. Борогонцы-Танда-Борогонцы

Выезд в 12:00ч

Прибытие в 14:30ч

-посещение Тандинского исторического-революционного музея им.Готовцева

Отъезд в 16:00ч

Прибытие в Борогонцы 18:30ч

-ужин (не включен)

-гостиница.

3 день. Борогонцы-Дюпсэ-Якутск.

Выезд Борогонцы - Дюпсэ 9:00 ч.

Прибытие 12:00 ч.

- экскурсия по Музеи космонавтики и авиации им.Ю.А.Гагарина

- обед (не включен)

Прибытие в Борогонцы 18 ч.

4 день. Борогонцы-Якутск 
- выезд в 09:00ч

- прибытие 15:00ч

Включено:

-услуга сопровождающего гида-экскурсовода;

-входные билеты в музей-заповедник «Дружба» - 250 рб.;

-входные билеты в Борогонский краеведческий музей - 250 рб.;

-проживание в гостинице «Мюрю» - 1000 рб. в сутки с одного человека;

-входные билеты в Тандийский музей в день - 150 рб.

Не включено:

-питание;

-личная теплая одежда;

-активности, не предусмотренные программой тура. 